\title{
Effect of Different Cooking Techniques on Microbial, Sensory and Colour Characteristics of Fish Pâté: Comparison of Ohmic and Traditional Cooking Techniques
}

\author{
Cem AYDIN ${ }^{1}$, Ünal KURT ${ }^{2}$, Yalçın KAYA ${ }^{3}$
}

\begin{abstract}
The objective of this research was to investigate the quality characteristics of fish pâté produced using different cooking techniques. For this purpose, the fish pâté was cooked by ohmic and traditional (water bath) cooking techniques to same target temperature $\left(78{ }^{\circ} \mathrm{C}\right)$. The time required for pasteurization of ohmic cooked fish pâté (OC) was calculated as 473.82 minutes, which is shorter than the pasteurization value of traditionally cooked fish pâté (TC) calculated as $2696.23 \mathrm{~min}$. However, total bacteria count (TBC) and total yeast and mold count (TYM) of OC and TC were not ( $>0.05$ ) statistically different. Although the $\mathrm{L}^{*}$ and $\mathrm{a}^{*}$ colour values of $\mathrm{OC}$ and TC were not significantly different $(p>0.05)$, these colour values were significantly different $(p<0.05)$ from the values of uncooked fish pâté (UC). After cooking process, the sensory score of OC was higher than the sensory score of TC according to appearance, flavour and odour score. On the other hand, the deterioration of $\mathrm{OC}$ was occurred faster than the deterioration of TC during cold storage $\left(4^{\circ} \mathrm{C}\right)$ of fish pâtés. OC was evaluated "unacceptable" at the $20^{\text {th }}$ day of storage when TC was evaluated as "acceptable" on the same day of storage. In the view of such information, it has been determined that further optimization studies are needed in order to use the ohmic cooking technique, which has a unique heating mechanism, in the cooking of fish pâté.
\end{abstract}

Keywords: Fish pâté, ohmic cooking, cold storage, quality characteristics

\section{Farklı Pişirme Tekniklerinin Balık Ezmenin Mikrobiyal, Duyusal ve Renk Karakteristiklerine Etkisi: Ohmik ve Geleneksel Pişirme Tekniklerinin Karşılaştırılması}

\section{$\ddot{O Z Z}$}

$\mathrm{Bu}$ araştırmanın amacı farklı pişirme teknikleri kullanılarak üretilen balık ezmesinin kalite karakteristiklerini incelemektir. Bu amaçla balık ezmesi ohmik ve geleneksel (su banyosu) pişirme teknikleri ile aynı hedef sıcaklığa $\left(78^{\circ} \mathrm{C}\right)$ kadar 1 sıtılmıştır. Ohmik yöntemle pişirilmiş balık ezmesinin (OC) pastörizasyonu için gereken süre $473.82 \mathrm{dk}$. olarak hesaplanmıştır ve bu değer, geleneksel yöntemle pişirilmiş balık ezmesinin (TC) $2696.23 \mathrm{dk}$. olarak hesaplanan pastörizasyon süresinden daha kısadır. Bununla birlikte, OC ve TC 'nin toplam bakteri sayısı (TBC) ve toplam maya-küf sayısı (TYM) istatistiksel olarak farklı ( $>0.05)$ bulunmamıştır. OC ve TC 'ye ait $\mathrm{L}^{*}$ ve $a^{*}$ renk değerleri önemli bir farklılık ( $\left.p>0.05\right)$ göstermese de bu renk değerleri pişirilmemiş balık ezmesine (UC) ait $\mathrm{L}^{*}$ ve $\mathrm{a}^{*}$ renk değerlerinden önemli derecede farklılı $(\mathrm{p}<0.05)$ göstermiştir. Pişirme işlemi sonrasında, görünüm, tat ve koku değerlerine göre $\mathrm{OC}$ 'nin duyusal beğeni puanları, TC'den daha yüksek olmuştur. Diğer yandan, balık ezmelerin soğuk ortamda $\left(4^{\circ} \mathrm{C}\right)$ depolanması sırasında, OC'deki bozulma, TC'deki bozulmadan daha hızlı gerçekleşmiştir. OC depolamanın 20. gününde "kabul edilemez" olarak değerlendirilirken, TC aynı depolama gününde "kabul edilebilir" olarak değerlendirilmiş̧tir. Bu bilgiler ışığında, kendine özgü 1sıtma mekanizması olan ohmik

Yayın Kuruluna Geliş Tarihi: 28.06.2021

Kabul Tarihi: 04.12.2021

${ }^{1}$ Agriculture And Rural Development Support Institution, Amasya Provincial Coordination Unit, Amasya, Turkey.

${ }^{2}$ Technology Faculty, Electrical and Electronics Engineering, Amasya University, Amasya, Turkey ${ }^{3}$ Faculty of Fisheries,Department of Fish Processing Technology, Sinop University, Sinop, Turkey *E-posta: cmydns@gmail.com 


\section{Effect of Different Cooking Techniques on Microbial, Sensory and Colour \\ Characteristics of Fish Pâté: Comparison of Ohmic and Traditional Cooking Techniques}

pişirme tekniğinin, balık ezmesinin pişirilmesinde kullanılabilmesi için daha ileri optimizasyon çalışmalarına ihtiyaç duyulduğu tespit edilmiştir.

Anahtar kelimeler: Balık ezmesi, ohmik pişirme, soğuk depolama, kalite karakteristikleri

ORCID ID (Yazar sırasına göre)

0000-0002-5011-2225, 0000-0002-8889-8681, 0000-0002-1259-2336

\section{Introduction}

Heating is the most widely used technique to increase shelf life and improve digestibility in food processing. Conventional heating techniques use substantial time and enormous energy to convey heat from the outer layer to the coldest point of the food products to achieve the target temperature for safety consideration.

Although conventional heating techniques are able to provide microbiological safety, the intense heating nature of conventional techniques generally causes overheating problems, which may adversely affect the nutritional value and sensory characteristics of heated foods. Therefore, novel thermal technologies such as ohmic heating, have been the subject of researches in order to prevent the thermal damage caused by conventional heating (Wills et al, 2006; Sarkis et al., 2013; Uran and Gokoglu, 2014; Tian et al., 2016; Turp et al., 2016.)

Ohmic heating is recognized as an emerging heating technology, based on a passage of electric current through the food.In ohmic heating, uniform temperature distribution occurs as a result of the fact that heat is generated in the whole volume of food product at the same time(İçier and Ilıcalı, 2005; Tornberg, 2013). By this way, ohmic heating provides high energy efficiency and fast heating rates with limited thermal damage (Dai et al., 2014; Aydın et al., 2020). In ohmic heating, as compared to conventional heating techniques, the energy efficiency and the decrease of process time were reported at about $90 \%$ and $50 \%$, respectively. (Zell et al., 2009; Aydin et al., 2020). On the other hand, researchers have been conducted on the disadvantages of ohmic heating, such as insufficient microbial inactivation and colour formation of food products(Sengun et al., 2014; Bozkurt and İçier, 2010; Kendirci et al., 2014; Turp et al., 2016). However, it was stated that differences in process parameters of ohmic heating and in the design of ohmic system could affect the results of researches on physical, chemical and microbiological parameters of ohmically heated food products(Yildiz-Turp et al., 2013).So, exploring the quality parameters of various food types under different ohmic heating conditions makes considerable contributions to the limited knowledge about ohmic heating mechanisms as a novel food processing technology. The aim of this research was to study and compare the effects of ohmic and conventional heating on the microbial, sensory and colour characteristics of fish pâté.

\section{Materials and Methods \\ Preparation of Fish pâté}

The fish pâté was produced according to the previous study (Aydin et al., 2020). As a raw material, rainbow trout (Oncorhynchus mykiss, Walbaum, 1792) were obtained from a local fish farm in Samsun, Turkey. The fishes were eviscerated, be headed and filleted.

The fillets were steeped in $20 \%$ (w/ v) brine solution for $60 \mathrm{~min}$. Then, hot smoking process was carried out in smoking oven (Apparatebau Gunther Kronawitter, Wallersdorf, Germany) and beech tree sawdust was used to produce smoke. After hot smoking process, the fillets were cooled and skins were removed. The skinless hot-smoked fish fillets were minced by a grinder machine (EKIY-182121, Tulsan, Turkey). Finally, minced fish meat was mixed with the ingredients according to the following formula: meat $(\% 91.5 \mathrm{w} / \mathrm{w})$, butter $(\% 8.1 \mathrm{w} / \mathrm{w})$, powdered onion $(\% 0.3 \mathrm{w} / \mathrm{w})$ and black pepper (\% $0.1 \mathrm{w} / \mathrm{w})$.

\section{Ohmic Cooking Procedure}

An ohmic heating device was designed as expressed by Aydın et al. (2020). Ohmic heating apparatus, made up of rectangular temperedglass, was connected to a $2.5 \mathrm{kVA}$ power supply 


\section{Effect of Different Cooking Techniques on Microbial, Sensory and Colour \\ Characteristics of Fish Pâté: Comparison of Ohmic and Traditional Cooking Techniques}

$(50 \mathrm{~Hz}, 0-4300 \mathrm{~V})$. The gap between two parallel stainless steel (316) electrodes were 10 $\mathrm{cm}$ and the electrodes were connected to the fish pâté. The temperature change at the center of heating cell was monitored by using K-type thermocouple during the heating process. The fish pâté samples were heated with $5 \mathrm{~V} / \mathrm{cm}$ voltage gradient and $50 \mathrm{~Hz}$ frequency to reach set temperature $78^{\circ} \mathrm{C}$.

\section{Traditional Cooking Procedure}

Fish pâté was placed into glass jars (KP82, Sisecam, Turkey) that each contains $135 \mathrm{~g}$ of sample. Then, the samples were cooked to $78^{\circ} \mathrm{C}$ in water bath (WB-22, Wisetherm, Korea) set at $98 \pm 1{ }^{\circ} \mathrm{C}$. When the temperature reached to target temperature, all samples cooked by ohmic (OC) and traditional (TC) technique were cooled for a while at room temperature. After cooling period, samples were stuffed in cylindrical boxes (PP-60, LP Italiana, Italy) and ohmic cooked (OC) and traditional cooked (TC) pâté samples stored at $4 \pm 1{ }^{\circ} \mathrm{C}$ for 20 days. Analyses were carried out at the beginning and $4^{\text {th }}, 8^{\text {th }}, 12^{\text {th }}, 16^{\text {th }}$ and $20^{\text {th }}$ days of storage period.

\section{Pasteruzation Value (PV) Calculation}

During cooking processes, pasteruzation value of pâté samples was calculated by the following equation (McKella et al., 2006);

$$
P V=\int_{0}^{t} 10^{\frac{T-60}{5.5}} d t
$$

where $\mathrm{T}$ is the temperature of coldest point of pâté samples during cooking and $t$ is the total time (min) for cooking process. The pasteruzation values $(\mathrm{min})$ below $55^{\circ} \mathrm{C}$ were not taken into account because of small values.

\section{Colour Analysis}

Color measurements of uncooked and cooked pâté samples were made by using a Minolta colorimeter (Model No. CR-400). Color coordinates in CIE Lab L*, $\mathrm{a}^{*}, \mathrm{~b}^{*}$ were recorded. The CIE Lab L*, $a^{*}$, and $b^{*}$ values correspond to lightness $\left(\mathrm{L}^{*}\right)$, redness $\left(\mathrm{a}^{*}\right)$, and yellowness, $\left(b^{*}\right)$, respectively. Eight readings were performed for each condition.

\section{Microbial Analysis}

Total bacteria count (TBC) and total yeast and mold counts (TYM) of fish pâté were used to determine microbial quality of cooking techniques. At the beginning, ten grams of pâté sample from each group (OC, TC) was added to sterile bag with $90 \mathrm{~mL}$ sterile physiological saline (\% 0.85) and was homogenized using stomacher. Then, 10-fold dilutions were prepared using the same diluents up to $10^{-7}$ in duplicate in growth media. (Gürgün and Halkman, 1990). Plate count agar (PCA) were used for the total bacteria counts (TBC) and the inoculated plates were incubated at $28^{\circ} \mathrm{C}$ for 72 h. The total yeast and mold counts (TYM) were detected using potatoes dextrose agar (PDA) incubated at $28^{\circ} \mathrm{C}$ for $72 \mathrm{~h}$ (Göktan, 1990; Varlık et al.,1993). Analyses were performed with 3 replicate trials for every duplicate sample. The counts were reported as log cfu/g.

\section{Sensory Analysis}

Sensory analysis of fish pâté was performed by five trained panellists, who were asked to evaluate appearance, flavour, odour and texture.Nine-point descriptive scale was used for analyses described by Schormüller (1968) and modified by Varlık et al. (1993).

According to scale, a score higher than 5.0 were evaluated as "good quality", a score of 5.0-4.0 indicated "limit of acceptable quality", a score of 3.9-1.0 indicated "unacceptable quality".

\section{Statistical analysis}

Data sets were tested to regarding normal distribution by the Shapiro-Wilk test and Kolmogorov-Smirnoff. For data's with normal distribution, statistical differences between the groups were determined by performing analysis of variance (one-way ANOVA) and Tukey's test was applied for post hoc comparisons. Sensory analysis results with non-normal distribution were tested by non-parametric procedures for independent samples (Kruskal-Wallis and Mann-Whitney U). All statistical calculations were performed using SPSS 17.0 (SPSS Inc., Chicago, IL, USA). The level of confidence was \% 95 (Sümbüloğlu and Sümbüloğlu, 2000). All datas were given as mean values \pm standard error.

\section{Result and Discussion}




\section{Effect of Different Cooking Techniques on Microbial, Sensory and Colour \\ Characteristics of Fish Pâté: Comparison of Ohmic and Traditional Cooking Techniques}

\section{PV Calculations}

Pasteurization value is a term of lethality level at reference temperature and it is also used to evaluate the inhibition effect of heating process on microorganisms (McKenna et al., 2006). In this research, the PV of TC were higher than the $\mathrm{PV}$ of $\mathrm{OC}$ in all temperatures and as the temperature increased, the difference between $\mathrm{PV}$ of TC and OC also increased. For instance, the $\mathrm{PV}$ of $\mathrm{TC}$ and $\mathrm{OC}$ at $58^{\circ} \mathrm{C}$ was $0.31 \mathrm{~min}$ and 0.17 min (Table 1) and the PV of TC and OC at $75^{\circ} \mathrm{C}$ was 872.45 and 193.85 min respectively. At the end of heating processes, the total PV of OC and TC was calculated as $473.82 \mathrm{~min}$ and $2696.23 \mathrm{~min}$ respectively. The total pasteurization effect of TC was 5,69 times higher than the total pasteurization effect of OC. The pasteurization effect of different heating techniques was also investigated by several researchers. Sengun et al. (2017) reported that the pasteurization effect of ohmic - infrared combination heating technique was changed between the range of $50.5-7.83 \times 10^{8} \mathrm{~min}$ due to the process parameters. The pasteurization effect of ohmic and traditional heating at cold point was also stated by Zell et al. (2009), as 2800 and $1480 \mathrm{~min}$, respectively. McKenna et al. (2006) heated the different meat samples by radio-frequency and steam cooking technique at $72{ }^{\circ} \mathrm{C}(2 \mathrm{~min})$ and found that the pasteurization value of steam cooking was approximately 5 times higher than the pasteurization value of radio-frequency cooking. These results were in accordance with our results. As ohmic and traditional cooking compared, the rate of temperature increase at ohmic heating was higher than the traditional heating, so the process time to reach set temperature was shortened in ohmic cooking process. It was evaluated that the differences between the pasteurization values in literature associated with the time-temperature profile of heating technique. That is why, it was recommended that the cooking process was checked not only by the control of target temperature, but also checked by the timetemperature profile (Matsui et al., 2008).

Table 1 Pasteurization values (min) of ohmic and traditional cooked fish pâté

\begin{tabular}{cccc}
\hline Temperature $\left({ }^{\circ} \mathrm{C}\right)$ & OC & TC & Ratio (TC/OC) \\
\hline 55 & $0.02 \pm 0.00$ & $0.03 \pm 0.01$ & 1,50 \\
58 & $0.17 \pm 0.01$ & $0.31 \pm 0.11$ & 1,80 \\
60 & $0.44 \pm 0.04$ & $0.96 \pm 0.22$ & 2,20 \\
63 & $1.54 \pm 0.16$ & $3.28 \pm 0.89$ & 2,13 \\
65 & $3.87 \pm 0.57$ & $8.21 \pm 2.00$ & 2,12 \\
68 & $12.85 \pm 0.82$ & $30.45 \pm 9.22$ & 2,37 \\
70 & $29.21 \pm 2.27$ & $76.29 \pm 16.53$ & 2,61 \\
73 & $90.63 \pm 0.08$ & $329.29 \pm 37.28$ & 3,63 \\
75 & $193.85 \pm 14.66$ & $872.45 \pm 50.97$ & 4,50 \\
78 & $473.82 \pm 38.46$ & $2692.23 \pm 270.78$ & 5,69 \\
\hline \hline
\end{tabular}

OC: ohmic cooked fish pâté, TC: traditional cooked fish pâté, 


\section{Effect of Different Cooking Techniques on Microbial, Sensory and Colour \\ Characteristics of Fish Pâté: Comparison of Ohmic and Traditional Cooking Techniques}

\section{Colour Analysis}

One of the critical characteristics of meat and meat products is its colour which influences the consumer's decision on purchase and consumption (Engchuan et al., 2014) and the cooking process had substantial effect on the colour of meat and meat products (Dai et al., 2013). The colour changes of UC, OC and TC can be observed from Table 2 .

Table 2 Colour properties of ohmic and traditional cooked fish pâté during cold $\left(4^{\circ} \mathrm{C}\right)$ storage

\begin{tabular}{|c|c|c|c|c|c|c|}
\hline \multirow[b]{2}{*}{$\begin{array}{l}\text { Storage Time } \\
\text { (day) }\end{array}$} & \multicolumn{2}{|c|}{$\mathrm{L}$} & \multicolumn{2}{|c|}{$\mathrm{a}$} & \multicolumn{2}{|c|}{$\mathrm{b}$} \\
\hline & $\mathrm{OC}$ & $\mathrm{TC}$ & $\mathrm{OC}$ & $\mathrm{TC}$ & $\mathrm{OC}$ & $\mathrm{TC}$ \\
\hline $\mathrm{UC}$ & \multicolumn{2}{|c|}{$69,90 \pm 0,06^{\mathrm{a}}$} & \multicolumn{2}{|c|}{$3,69 \pm 0,04^{\mathrm{b}}$} & \multicolumn{2}{|c|}{$21,34 \pm 0,12^{\mathrm{b}}$} \\
\hline 0 & $70,99 \pm 0,05^{\mathrm{CDb}}$ & $71,06 \pm 0,02^{\mathrm{Ab}}$ & $3,26 \pm 0,02^{\mathrm{Da}}$ & $3,44 \pm 0,08^{\mathrm{Da}}$ & $21,36 \pm 0,09^{\mathrm{ABb}}$ & $20,89 \pm 0,06^{\mathrm{Aa}}$ \\
\hline 4 & $71,47 \pm 0,14^{\mathrm{Ba}}$ & $71,59 \pm 0,09^{\mathrm{Ba}}$ & $3,21 \pm 0,03^{\mathrm{Da}}$ & $2,96 \pm 0,07^{\mathrm{Cb}}$ & $21,83 \pm 0,14^{\mathrm{BCa}}$ & $21,78 \pm 0,14^{\mathrm{Ba}}$ \\
\hline 8 & $71,06 \pm 0,11^{\mathrm{BCa}}$ & $71,12 \pm 0,09^{\mathrm{Aa}}$ & $2,76 \pm 0,06^{\mathrm{Ca}}$ & $2,64 \pm 0,08^{\mathrm{BCa}}$ & $21,72 \pm 0,12^{\mathrm{ABCa}}$ & $21,03 \pm 0,12^{\mathrm{Ab}}$ \\
\hline 12 & $70,97 \pm 0,10^{\mathrm{CDa}}$ & $71,50 \pm 0,09^{\mathrm{Bb}}$ & $2,31 \pm 0,07^{\mathrm{Ba}}$ & $2,48 \pm 0,02^{\mathrm{Ba}}$ & $21,73 \pm 0,09^{\mathrm{ABCa}}$ & $21,34 \pm 0,10^{\mathrm{ABb}}$ \\
\hline 16 & $70,54 \pm 0,10^{\mathrm{ADa}}$ & $71,66 \pm 0,09^{\mathrm{Bb}}$ & $2,35 \pm 0,07^{\mathrm{Ba}}$ & $2,00 \pm 0,04^{\mathrm{Ab}}$ & $21,27 \pm 0,12^{\mathrm{Aa}}$ & $20,90 \pm 0,09^{\mathrm{Ab}}$ \\
\hline 20 & $70,41 \pm 0,11^{\mathrm{Aa}}$ & $70,92 \pm 0,01^{\mathrm{Ab}}$ & $2,02 \pm 0,04^{\mathrm{Aa}}$ & $1,71 \pm 0,03^{\mathrm{Ab}}$ & $21,84 \pm 0,05^{\mathrm{Ca}}$ & $21,25 \pm 0,06^{\mathrm{Ab}}$ \\
\hline
\end{tabular}

Different small letters $(\mathrm{a}, \mathrm{b})$ represent significant difference among groups $(\mathrm{P}<0.05)$. Different capital letters $(\mathrm{A}, \mathrm{B}$,$) represent significant difference among different days within the same group during storage (\mathrm{P}<0.05)$. UC: uncooked fish pâté, OC: ohmic cooked fish pâté, TC: traditional cooked fish pâté,

The $\mathrm{L}^{*}$ and $\mathrm{a}^{*}$ values of OC and TC were not significantly different $(\mathrm{p}>0.05)$ at the beginning of storage, but these values were significantly different $(\mathrm{p}<0.05)$ from the $\mathrm{L}^{*}$ and $\mathrm{a}^{*}$ values of uncooked (UC) samples.

Both ohmic and traditional cooking were substantial affected on the colour of $\mathrm{L}^{*}$ and $\mathrm{a}^{*}$ values of pâté samples. On the other hand, the $b^{*}$ values of TC were significantly different $(p<0.05)$ from the $b^{*}$ values of OC and UC.

During storage of pâté samples, the $\mathrm{L}^{*}$ and $\mathrm{a}^{*}$ values of OC and TC fluctuated but showed a tendency of decrease in general. The $\mathrm{L}^{*}$ and $\mathrm{b}^{*}$ value of UC, OC and TC were lower, the $\mathrm{a}^{*}$ value of UC, OC and TC were higher than the values reported by Daaroonpunt et al. (2016) and Amaral et al. (2015). The colour difference of fish pâté samples might have occurred due to cooking loss, denaturation of proteins and oxidation reactions as a result of different rate of temperature increase during the cooking process (Shibukawa et al., 1989; Estevez and Cava, 2004; Ganhao et al., 2010).

\section{Microbial Analysis}

The microbial load of a food product has a direct relation with quality of food, so the microbial analysis is the one of the most frequently used methods to decide the quality and shelf life. OC and TC were heated to same target temperature $\left(78^{\circ} \mathrm{C}\right)$. TBC and TYM of OC and TC (Figure 1 and Figure 2) were not significantly different $(p>0.05)$ at the beginning of storage. The difference was found significant $(\mathrm{p}<0.05)$ during cold storage of fish pâté in all analyse days.

Meat and meat products consist of components with different electrical conductivity such as protein, fat, water and spices. When the meat and meat products were cooked by ohmic cooking technique, the parts with bad electrical conductivity were not heated as good as the parts with good electrical conductivity. So, during 


\section{Effect of Different Cooking Techniques on Microbial, Sensory and Colour \\ Characteristics of Fish Pâté: Comparison of Ohmic and Traditional Cooking Techniques}

ohmic cooking, some insufficient heated parts may be occurred (Shirsat et al., 2004; McKenna et al., 2006; Sarang et al., 2008).

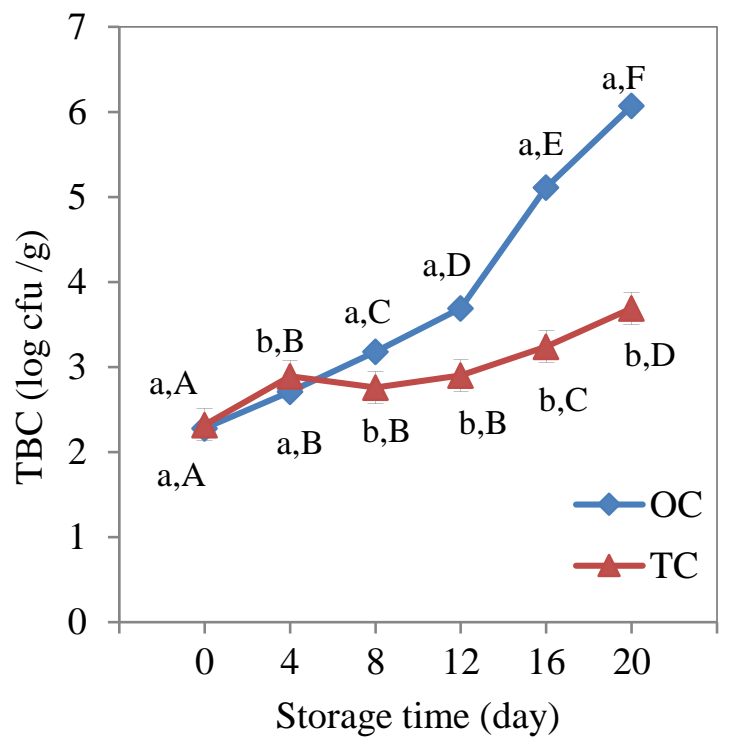

Figure 1. TBC of ohmic and traditional cooked fish pate during cold $\left(4^{\circ} \mathrm{C}\right)$ storage

Different small letters $(a, b)$ represent significant difference among groups $(\mathrm{P}<0.05)$. Different capital letters $(\mathrm{A}, \mathrm{B}$,$) represent significant$ difference amongst different days within the same group during storage $(\mathrm{P}<0.05)$. OC: ohmic cooked fish pâté, TC: traditional cooked fish pâté,

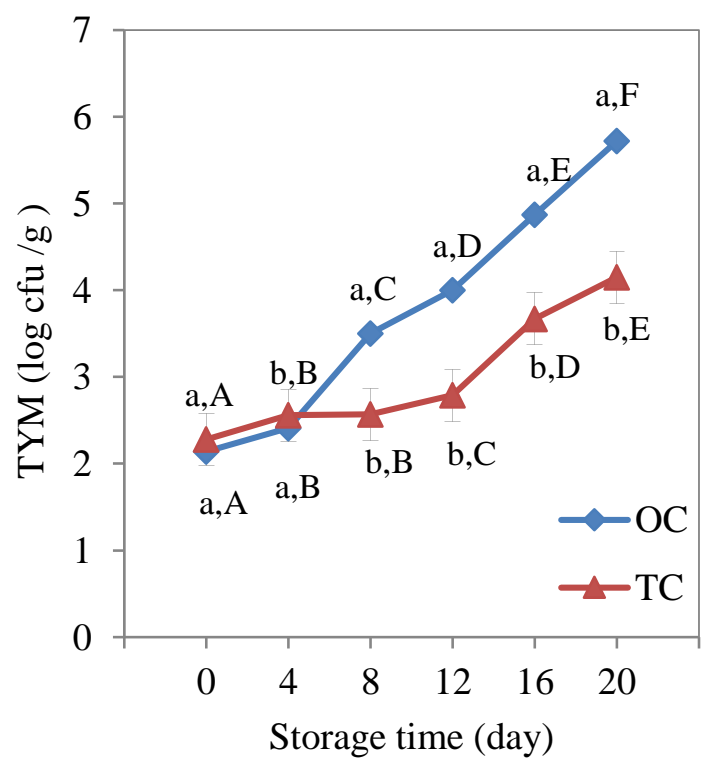

Figure 2. TYM of ohmic and traditional cooked fish pate during cold $\left(4^{\circ} \mathrm{C}\right)$ storage
Different small letters $(\mathrm{a}, \mathrm{b})$ represent significant difference among groups $(\mathrm{P}<0.05)$. Different capital letters (A,B) represent significant difference amongst different days within the same group during storage $(\mathrm{P}<0.05)$. OC: ohmic cooked fish pâté, TC: traditional cooked fish pâté,

Sengün et al. (2017) stated that the ohmic cooking technique decreased the process time in half, but it might be insufficient to ensure desired microbial safety. In our study, fatty parts of OC may not be cooked enough due to bad electrical conductivity, thus these parts may be not pasteurised enough. And by the contribution of microbial load at unpasteurised parts, microbial deterioration of OC may be faster than microbial deterioration of TC during storage. At end of storage, TBC of OC was exceeded the limit of 6 $\log \mathrm{cfu} / \mathrm{g}$ and $\mathrm{OC}$ was determined as "unacceptable" (ICMSF, 1986; Nickelson and Finne 1992; Çakmak and Çolak, 2004; Erkan and Özden, 2007).

\section{Sensory properties of fish pâté}

Sensory score of fish pâté was presented in Table 3. Flavour scores of $\mathrm{OC}$ and $\mathrm{TC}$ showed significant difference $(p<0.05)$ after cooking process. Subsequently, the significant difference $(\mathrm{p}<0.05)$ between OC and TC remained unchanged during cold storage. The flavour score of OC was lower than the flavour of OC at the $16^{\text {th }}$ day. The flavour score at $20^{\text {th }}$ day of storage of OC were found 3.80 and $\mathrm{OC}$ was evaluated as "unacceptable quality". Up to $16^{\text {th }}$ day of storage, there were no significant difference $(p>0.05)$ between the texture scores of $\mathrm{OC}$ and TC. According to the texture score of $\mathrm{OC}$, it was evaluated as "unacceptable quality" at 20th day. Amaral et al. (2015) studied the change of sensory properties of cooked pâté samples during storage and explained that the appearance, odour, flavour and texture quality of samples were deteriorated during storage and shelf life of pâté samples were reported as 30 days $\left(4^{\circ} \mathrm{C}\right)$. Zell et al. (2010) stated that the appearance and texture score of ohmic cooked meat were higher than the score of traditional cooked meat as similar to our study. Bozkurt and İçier (2010) compared the ohmic and traditional 


\section{Effect of Different Cooking Techniques on Microbial, Sensory and Colour \\ Characteristics of Fish Pâté: Comparison of Ohmic and Traditional Cooking Techniques}

cooked meat products in their research and concluded that the cooking technique had significant effect on meat quality, especially on texture. The flavour and texture quality changes of pâté samples are in agreement with the findings of Siret and Issanchou (2000) who stated that the flavour and texture characteristics were the most effective sensory attributes on pâté quality.Due to different time-temperature profile of OC and TC, physical and chemical reactions might be effected the sensory attributes of pâté samples in different degrees. It was also decided that the quality loss occurred during storage could be a result of chemical and bacteriological changes (Dainty and Mackey, 1992; Bremner et al., 2002).

Table 3. Sensory scores of ohmic and traditional cooked fish pate during cold $\left(4^{\circ} \mathrm{C}\right)$ storage

\begin{tabular}{|c|c|c|c|c|c|c|c|c|}
\hline \multirow{2}{*}{$\begin{array}{c}\text { Storage } \\
\text { Time } \\
\text { (day) }\end{array}$} & \multicolumn{2}{|c|}{ Appearance } & \multicolumn{2}{|c|}{ Odour } & \multicolumn{2}{|c|}{ Flavour } & \multicolumn{2}{|c|}{ Texture } \\
\hline & OC & $\mathrm{TC}$ & OC & $\mathrm{TC}$ & OC & $\mathrm{TC}$ & OC & $\mathrm{TC}$ \\
\hline 0 & $\begin{array}{c}7,80 \pm 0,13^{\mathrm{C}} \\
\text { a }\end{array}$ & $\begin{array}{c}7,10 \pm 0,10^{\mathrm{C}} \\
\mathrm{b}\end{array}$ & $\begin{array}{c}7,90 \pm 0,10^{\mathrm{C}} \\
\mathrm{a}\end{array}$ & $\begin{array}{c}7,10 \pm 0,18^{\mathrm{C}} \\
\mathrm{b}\end{array}$ & $\begin{array}{c}7,90 \pm 0,10^{\mathrm{C}} \\
\mathrm{a}\end{array}$ & $\begin{array}{c}7,10 \pm 0,18^{\mathrm{B}} \\
\text { b }\end{array}$ & $\begin{array}{c}7,40 \pm 0,16^{\mathrm{C}} \\
\text { a }\end{array}$ & $\begin{array}{c}6,90 \pm 0,18^{B} \\
\text { a }\end{array}$ \\
\hline 4 & $\begin{array}{c}7,00 \pm 0,00^{\mathrm{B}} \\
\mathrm{a}\end{array}$ & $\underset{\mathrm{Ca}}{6,80 \pm 0,13^{\mathrm{B}}}$ & $\begin{array}{c}7,80 \pm 0,13^{C} \\
a\end{array}$ & $\begin{array}{c}7,00 \pm 0,21^{C} \\
b\end{array}$ & $\begin{array}{c}7,80 \pm 0,13^{C} \\
a\end{array}$ & $\begin{array}{c}6,90 \pm 0,18^{\mathrm{B}} \\
\mathrm{b}\end{array}$ & $\begin{array}{c}7,00 \pm 0,00^{C} \\
\text { a }\end{array}$ & $\underset{a}{6,90 \pm 0,10^{B}}$ \\
\hline 8 & $\begin{array}{c}7,00 \pm 0,00^{\mathrm{B}} \\
\mathrm{a}\end{array}$ & $\begin{array}{c}6,70 \pm 0,15^{\mathrm{A}} \\
\mathrm{BCb}\end{array}$ & $\begin{array}{c}7,90 \pm 0,10^{\mathrm{C}} \\
\mathrm{a}\end{array}$ & $\underset{\mathrm{Cb}}{6,80 \pm 0,13^{\mathrm{B}}}$ & $\begin{array}{c}7,40 \pm 0,16^{\mathrm{C}} \\
\mathrm{a}\end{array}$ & $\begin{array}{c}6,90 \pm 0,10^{\mathrm{B}} \\
\mathrm{b}\end{array}$ & $\underset{\mathrm{a}}{6,90 \pm 0,10^{\mathrm{C}}}$ & $\underset{a}{6,60 \pm 0,16^{\mathrm{B}}}$ \\
\hline 12 & $\underset{\mathrm{Ba}}{6,70 \pm 0,15^{\mathrm{A}}}$ & $\begin{array}{c}6,50 \pm 0,17^{\mathrm{A}} \\
\mathrm{BCa}\end{array}$ & $\begin{array}{c}7,10 \pm 0,10^{\mathrm{B}} \\
\mathrm{a}\end{array}$ & $\begin{array}{c}6,70 \pm 0,15^{\mathrm{A}} \\
\mathrm{BCb}\end{array}$ & $\underset{\mathrm{a}}{7,30 \pm 0,15^{\mathrm{C}}}$ & $\begin{array}{c}6,80 \pm 0,13^{\mathrm{B}} \\
\mathrm{b}\end{array}$ & $\begin{array}{c}6,80 \pm 0,13^{C} \\
a\end{array}$ & $\underset{a}{6,60 \pm 0,16^{\mathrm{B}}}$ \\
\hline 16 & $\underset{\mathrm{Ba}}{6,60 \pm 0,16^{\mathrm{A}}}$ & $\begin{array}{c}6,30 \pm 0,15^{\mathrm{A}} \\
\mathrm{Bb}\end{array}$ & $\underset{\mathrm{a}}{6,30 \pm 0,15^{\mathrm{A}}}$ & $\begin{array}{c}6,30 \pm 0,15^{\mathrm{A}} \\
\mathrm{Ba}\end{array}$ & $\underset{\mathrm{a}}{5,80 \pm 0,25^{\mathrm{B}}}$ & $\underset{b}{6,50 \pm 0,17^{\mathrm{B}}}$ & $\underset{a}{5,20 \pm 0,25^{\mathrm{B}}}$ & $\underset{b}{6,30 \pm 0,15^{\mathrm{B}}}$ \\
\hline 20 & $\underset{\mathrm{a}}{6,30 \pm 0,15^{\mathrm{A}}}$ & $\underset{\mathrm{a}}{6,00 \pm 0,15^{\mathrm{A}}}$ & $\underset{\mathrm{a}}{6,20 \pm 0,13^{\mathrm{A}}}$ & $\underset{\mathrm{a}}{6,10 \pm 0,10^{\mathrm{A}}}$ & $\underset{\mathrm{a}}{3,80 \pm 0,20^{\mathrm{A}}}$ & $\begin{array}{c}5,60 \pm 0,16^{\mathrm{A}} \\
\mathrm{b}\end{array}$ & $\underset{\mathrm{a}}{3,60 \pm 0,16^{\mathrm{A}}}$ & $\begin{array}{c}5,40 \pm 0,22^{\mathrm{A}} \\
\mathrm{b}\end{array}$ \\
\hline
\end{tabular}

Different small letters $(\mathrm{a}, \mathrm{b})$ represent significant difference among groups $(\mathrm{P}<0.05)$. Different capital letters $(A, B, C$.$) represent significant difference amongst different days within the same group during storage$ $(\mathrm{P}<0.05)$. OC: ohmic cooked fish pâté, TC: traditional cooked fish pâté

\section{Conclusions}

It was determined that cooking methods had considerable impact on sensory attributes of fish pâté.As a novel cooking technique, fish pâté cooked by ohmically was preferable than the traditionally cooked ones. There was not any difference between the microbiological and colour properties of fish pâté cooked by ohmic and traditional heating technique. On the other hand, the quality parameters of fish pâté during cold storage were changed significantly due to the implemented cooking technique. Because of the heat transfer mechanism of cooking method, the intensity of heat transferred to food substantially changed. For that reason, when the ohmic cooking method were compared with any other methods, the control of pasteurisation value based on heat-temperature profile could be better to use instead of the control of target temperature during cooking process. Future research should be focused on optimisation of ohmic cooking process as a promising technology, to achieve better understanding.

\section{Acknowledgement}

The datasets used in study entitled "Effects of cooking treatment on microbial, sensory and colour characteristics of fish pâté: Comparison of ohmic and traditional cooking techniques" was a part of $\mathrm{PhD}$ thesis "Determination of effects of ohmic heating process on fish pâté quality parameters".

\section{References}

Amaral, D.S., Silva, F.A.P., Bezerra, T.K.A., Arcanjo, N.M.O., Guerra, I.C.D., Dalmas, P.S., Madruga, M.S., (2015) Effect of storage time and packaging on the quality of lamb pate' prepared with variety meat. Food Packaging and Shelf Life, 3:39-46.

Aydın, C., Kurt Ü., Kaya, Y., (2020) Comparison of the Effects of Ohmic and Conventional Heating Methods on Some 


\section{Effect of Different Cooking Techniques on Microbial, Sensory and Colour \\ Characteristics of Fish Pâté: Comparison of Ohmic and Traditional Cooking Techniques}

Quality Parameters of the Hot-smoked Fish Pâté. Journal of Aquatic Food Product Technology, DOI: 10.1080/10498850.2020.1741752.

Bozkurt, H., Icier, F. (2010) Ohmic cooking of ground beef: Effects on quality. Journal of Food Engineering, 96, 481-490.

Bremner, A., Swings, S., John, D., (2002) Understanding the concepts of quality and freshness in fish. Safety and Quality Issues in Fish Processing, 2002;163-172.

Çakmak, S., Çolak, H., (2004) Su ürünleri mevzuatı ve yaptırımlar açısından değerlendirilmesi, T.C. Tarım ve Köyisleri Bakanlığ1 Koruma ve Kontrol Genel Müd., Ankara, 413 s.

Dai, Y., Lu, Y., Wu, W., Lu, X.M., Han, Z.P., Liu, Y., Li, X.M., Dai, R.T., (2014) Changes in oxidation, color and texture deteriorations during refrigerated storage of ohmically and water bath-cooked pork meat. Innov Food Sci Emerg Technol., 26:341-46.

Dai, Y., Miao, J., Yuan, S.Z., Liu, Y., Li, X.M., Dai, R.T., (2013) Colour and sarcoplasmic protein evaluation of pork following water bath and ohmic cooking. Meat Science, 93(4), 898-905. http://dx.doi.org/10.1016/j.meatsci.2012. 11.044.

Dainty, R.H., Mackey, B.M., (1992) The relationship between the phenotypic properties of bacteria from chill-stored meat and spoilage processes. Journal of Applied Bacteriology, 73:103-114.

Daroonpunt, R., Uchino, M., Tsujii, Y., Kazami, M., Oka, D., Tanasupawat, S., (2016) Chemical and physical properties of Thai traditional shrimp paste (Ka-pi). Journal of Applied Pharmaceutical Science, Vol. 6 (05), pp. 058-062.

Engchuan, W., Jittanit, W., Garnjanagoonchorn, W., (2014) The ohmic heating of meat ball: Modeling and quality determination. Innovative Food Science \& Emerging Technologies, 23, 121-130. http://dx.doi.org/10.1016/j.ifset.2014.02. 014.

Erkan, N., Özden, Ö., (2007) Quality assessment of whole and gutted sardines (Sardina pilchardus) stored in ice. International Journal of Food Science and Technology, 43(9),1549-1559.

Estevez, M., Cava, R., (2004) Lipid and protein oxidation, release of iron from heme molecule and colour deterioration during refrigerated storage of liver paté. Meat Science, 68, 551-558.

Ganhao, R., Morcuende, D., Estevez, M., (2010). Protein oxidation in emulsified cooked burger patties with added fruit extracts: influence on colour and texture deterioration during chill storage. Meat Sci., 85(3):402-409.

Göktan, D., (1990) Gidaların mikrobiyal ekolojisi. Ege Üniversitesi, Mühendislik Fak. Yayın No: 21, Ege Üniversitesi Basım Evi, İzmir, 292s.

Gürgün, V., Halkman, A.K., (1990) Mikrobiyolojide sayım yöntemleri. Gıda Teknolojisi Derneği, Yayın No: 7, San Matbaas1, Ankara, 146s.

Icier, F., Ilicali, C., (2005) The use of tylose as a food analog in ohmic heating studies. Journal of Food Engineering, 69, 67-77.

International Commission on Microbiological Specifications for Foods (ICMSF), (1986) Microorganisms in foods. Sampling for microbiological analysis: Principles and scientific applications, University of Toronto Press, Toronto.

Kendirci, P., Icier, F., Kor, G., Altug-Onogur, T., (2014) Influence of infrared final cooking on polycyclic aromatic hydrocarbon formation in ohmically pre-cooked beef meatballs. Meat Science, 97, 123-129.

Mancini, R.A., Hunt, M.C., (2005) Current research in meat color. Meat Science, 71(1), $100-121$. http://dx.doi.org/10.1016/j.meatsci.2005. 03.003 .

Matsui, K.N., Gut, J.A.W., de Oliveira, P.V., Tadini, C.C., (2008) Inactivation kinetics of polyphenol oxidase and peroxidase in green coconut water by microwave processing. Journal of Food Engineering, 88:169-176.

McKenna, B.M., Lyng, J., Brunton, N., Shirsat, N., (2006) Advances in radio frequency 


\section{Effect of Different Cooking Techniques on Microbial, Sensory and Colour \\ Characteristics of Fish Pâté: Comparison of Ohmic and Traditional Cooking Techniques}

and ohmic heating of meats. Journal of Food Engineering, 77: 215-229.

Nickelson, R., Finne. G., (1992) Fish, crustaceans, and precooked seafoods. In Vanderzant, C., Splittstoesser, D.F.(eds.), Ch.47. Compendium of Methods for the Microbiological Examination of Foods, 3rd edition, American Public Health Association, Washington, DC, p.875-895.

Sarang, S., Sastry, S.K., Knipe, L., (2008) Electrical conductivity of fruits and meats during ohmic heating. Journal of Food Engineering, 87(3):351-356.

Sarkis, J.R., Jaeschke, D.P., Tessaro, I.C., Marczak, L.D., (2013). Effects of ohmic and conventional heating on anthocyanin degradation during the processing of blueberry pulp. LWT-Food Science and Technology, 51(1), 79-85.

Schormüller, J., (1968) Handbuch der lebensmittelchemie (Band III/2), Springer-Verlag Berlin, pp.1341-1397.

Sengun, I.Y., Yildiz Turp, G., Icier, F., Kendirci, P., Kor, G., (2014) Effects of ohmic heating for pre-cooking of meatballs on some quality and safety attributes. $L W T$ Food Science and Technology, 55, 232239.

Sengun, I.Y., Icier, F., Kor, G., (2017) Effects of combined ohmic-nfrared cooking treatment on microbiological nnactivation of meatballs. Journal of Food Process Engineering, 40(1)2017: n/a, e12309. doi:10.1111/jfpe.12309.

Shibukawa, S., Sugiyama, K., Yano, T., (1989) Effect of heat transfer by radiation and convection on browning of cookies at baking. Journal of Food Science, 54, 621624.

Shirsat, N., Lyng, J.G., Brunton, N.P., McKenna, B.M., (2004) Conductivities and ohmic heating of meat emulsion batters. Journal of Muscle Foods, 15:121137.

Siret, F., Issanchou, S., (2000) Traditional process: influence on sensory properties and on consumers' expectation and liking application to 'pâté de campagne'. Food Qual. Prefer. 11, 217-228.
Sümbüloğlu, K., Sümbüloğlu, V., (2000) Biyoistatistik, Hatiboğlu Yayınları:53, 9.Bask1, Ankara.

Tian, X., Wu, W., Yu, Q., Hou, M., Jia, F., Li, X., Dai, R., (2016) Quality and proteome changes of beef $\mathrm{M}$. longissimus dorsi cooked using a water bath and ohmic heating process. Innovative Food Science \& Emerging Technologies, 34, 259-266.

Tornberg, E., (2013) Engineering processes in meat products and howthey influence their biophysical properties. Meat Science, 95, 871-878.

Turp, G.Y., Icier, F., Kor, G., (2016) Influence of infrared final cooking on color, texture and cooking characteristics of ohmically pre-cooked meatball. Meat Science, 114, 46-53.

Uran H, Gokoglu N., (2014) Effects of cooking methods and temperatures on nutritional and quality characteristics of anchovy (Engraulis encrasicholus). J Food Sci Technol., 51(4):722-28.

Varlık, C., Uğur, M., Gökoğlu, N., Gün, H., (1993) Su ürünlerinde kalite kontrol ilke ve yöntemleri. Gıda Teknolojisi Derneği Yayin No:17,1993 İstanbul.

Wills, T.M., Dewitt, C.A. M., Sigfusson, H., Bellmer, D., (2006) Effect of cooking method and ethanolic tocopherol on oxidative stability and quality of beef patties during refrigerated storage (oxidative stability of cooked patties). Journal of Food Science, 71(3), 109-114. https://doi.org/10.1111/j.13652621.2006.tb156 04.x.

Yildiz-Turp, G., Sengun, I. Y., Kendirci, P., İçier, F., (2013) Effect of ohmic treatment on quality characteristic of meat: A review. Meat Science, 93(3), 441-448.

Zell, M., Lyng, J.G., Cronin, D.A., Morgan, D.J., (2010) Ohmic cooking of whole turkey meat-Effect of rapid ohmic heating on selected product parameters. Food Chemistry, 120:724-729.

Zell M., Lyng J.G., Cronin D.A., Morgan D.J., (2009) Ohmic cooking of whole beef muscle-Optimisation of meat preparation. Meat Sci., 81(4):693-98. 
Effect of Different Cooking Techniques on Microbial, Sensory and Colour Characteristics of Fish Pâté: Comparison of Ohmic and Traditional Cooking Techniques 